\title{
Raising Hell in the Heartland: Filipino Chicago and the Anti-Martial Law Movement, 1972-1986
}

\author{
James Zarsadiaz
}

\section{Introduction}

At the age of twenty-six, Leo Constantino moved from the Philippines to the United States. The year was 1961, a time when Asian immigration was limited mostly to students, businessmen, and diplomats. Five years prior to his move, he was ordained a Methodist minister. He decided to pursue a doctorate at the University of Chicago's Divinity School. Initially, his time in Chicago was planned as a temporary sojourn, but Constantino wound up establishing roots in the city. Over the next four decades, he served as an influential Methodist pastor on the South Side, working closely with Chicago's Filipino Protestants. While he spent his earliest years in the Philippines, Constantino lived most of his life making a home in the Midwest, yet Constantino remained engaged with current events in the Philippines. An immigrant with strong nationalist views, Constantino always held out hope for social and political transformation in a nation ravaged with poverty, limited economic opportunities, and, by the 1970s, years of political instability under President Ferdinand Marcos's martial law order (1972-1986). Constantino participated in the anti-martial law movement by protesting the Marcos regime's violent tactics, militarism, extravagance, and severing of Filipinos' civil liberties. Filipino immigrants throughout the United States were outraged at what many believed were policies and actions undermining the integrity of the Philippines and its people living around the world. 
In Chicago, Filipino Americans across ideological, class, and religious backgrounds rallied together. This article examines the ways in which Chicago was a critical hub in the global anti-martial law movement. Perennially described in Asian American studies and Ethnic studies historiography as a coastal movement, I trace the ways in which Chicago and the greater Midwest played a central role in creating and sustaining a domestic and international anti-martial law movement. Contrary to stereotypes of Asian American "model minority" passivity or notions of midwestern social conformity, numerous radical and leftist organizations in Chicago raised community consciousness and pushed the boundaries of grassroots activism. Chicago-based religious groups and ethnic media also played a key role in the broader movement. Together, these Filipino American activists, even if they did not always agree, worked together and envisioned a world order for their homeland and for the global Philippine diaspora free of imperial ties and respectful of human rights.

Historical scholarship on Asian American - particularly Filipino American-experiences in the Midwest is limited since higher proportions reside in California, Hawaii, New York, and other traditional "immigrant gateway" states. Rather than dismissing the Midwest, scholars in the fields of American studies, Asian American studies, and Ethnic studies are called to recognize, first, the presence of Filipino Americans in the Midwest and, second, the significance of their leftist activism during the 1970s and 1980s. By placing the heart of the anti-martial law movement in America's figurative heartland, we are encouraged to understand the Filipino American experience from a unique position and different orientation.

Filipino Americans in the Midwest have long been on the margins of society and in the historical archive. Even less visible in midwestern Filipino American history are recorded moments or names of liberal, progressive, or radical activists who often clashed with conservative Filipinos championing American assimilation and the cultural politics of respectability. A modest body of literature on the anti-martial law movement produced in the late 1980s and 1990s documented Filipino activism in the Philippines and in the United States. ${ }^{1}$ However, with the exception of Jose Fuentecilla's 2013 book Fighting from a Distance, few studies on the movement have since emerged. ${ }^{2}$

Along with scholars, popular media and many anti-martial law activists privileged the coasts as the centers of leftist grassroots organizing; the San Francisco Bay Area, Los Angeles, New York City, and Seattle are often noted as the most recognizable hubs of Filipino American activism. Conspicuously invisible from these master narratives is the presence of liberal and radical activism in the Midwest, a region bemoaned for its culturally conservative leanings. This invisibility or even erasure of midwestern anti-martial law activism reflects both the activists' and the media's oversight of Chicago's grassroots movement and scholars' minimal knowledge or engagement with the midwestern Filipino American experience. 
This article does not suggest that Filipino American midwestern experiences were wholly exceptional. Instead, this story of the anti-martial law movement in Chicago reflects a commonality of social, political, cultural, and economic marginalization that Filipinos faced in other parts of the United States and the world. At the same time, Filipinos involved with the anti-martial law movement in Chicago were unique compared to their counterparts in San Francisco or New York; they pulled in the social justice wing of religious Protestant sects and creatively used ethnic media more successfully than activists in other cities.

\section{Early Settlement of Asian Americans and Filipino Americans in the Midwest}

Asian Americans have settled throughout the heartland since the mid1800s. They played a major role in helping develop America's economy of goods during the second industrial revolution. In the 1860s, Chinese laborers worked on the Transcontinental Railroad to construct one of the most significant transportation and infrastructure projects in US history. The Transcontinental Railroad benefited Midwest cities like Chicago as well as smaller metropolises like Kansas City and Omaha. In the realm of popular culture, Chinese and Filipino entrepreneurs and politicians participated at the world fairs of Chicago (1893) and St. Louis (1904). As more working-class Americans engaged in acts of "leisure," cultural booths and replicas, such as the "typical" Chinese theater or Filipino Igorot display, served as spaces where whites and Asians could interact albeit through the simulacra and optics of orientalism. From the mid-1950s through the 1980s, US interventions in Korea, Vietnam, Laos, and Cambodia brought displaced refugees and adoptees to the Midwest. This wave of individuals and families established ethnic enclaves in Michigan, Minnesota, and Wisconsin with the aid of the federal government (e.g., VOLAG), nonprofit organizations, and Protestant missionaries. ${ }^{3}$

Although unmapped from the typical geography of Filipino American settlement, Filipinos have settled throughout the Midwest since the early 1900s. ${ }^{4}$ Chicago, in particular, provided numerous educational and work opportunities. ${ }^{5}$ Beginning in 1903, during US colonial rule in the Philippines (1898-1946), Filipino students known as pensionados were sent to the United States to receive university educations. During their time in the United States, they learned the mores, civic principles, and practices of American democracy and were expected to relay this knowledge back to their provinces. Northwestern University, the University of Chicago, and especially the University of Illinois at Urbana-Champaign, were primary receivers of pensionados ${ }^{6}$ In the mid-1920s, the Pullman Rail Car Company hired Filipinos to replace African American porters who went on strike for higher wages and better treatment. ${ }^{7}$ After serving in the US military during World War II, Filipino men worked as bellhops, cooks, and custodians in Chicago hotels and office buildings. ${ }^{8}$ By the 1940s, approximately 1,740 Filipinos resided in Chicago. ${ }^{9}$ 
Three possible reasons explain this void in Asian American studies scholarship. First, Asian communities have historically concentrated along the coasts. Between the 1850s and 1940s, agricultural and fishery jobs, along with traditional factory and service work, attracted low-skilled, less educated immigrants to cities or regions like Seattle, Los Angeles, and California's Central Valley. The demographic profile of Asian immigrants who settled after the 1965 HartCeller Act diversified the class and ethnic backgrounds of Asian America. Yet the majority of new settlers continued to establish themselves in Los Angeles, New York, and San Francisco. An assumption that Asians in the Midwest were few or nowhere to be found contributed to this scholarly gap. Second, pre-1965 anti-Filipino sentiments in the United States were strongest in states with higher Filipino populations. The Midwest did not compare to the scale of tension and violence in California, Hawaii, and Washington. ${ }^{10}$ Filipinos in Chicago were no strangers to bigotry, but their presence and struggles remained in the shadows of the West Coast, where their presence was more palpable. Xenophobes blamed Filipinos for taking away job opportunities from native-born whites, resulting in riots and anti-immigrant legislation. ${ }^{11}$ Finally, since the Yellow Power/Third World Liberation and Asian American studies movements trace their origins to the San Francisco Bay Area, scholars since the 1970s have been trained with these regional biases. In turn, their models and frameworks for understanding Asian American subjectivities and experiences skewed west, creating false dichotomies of Asian American narratives. ${ }^{12}$ Recent works by Pawan Dhingra, Kale Fajardo, Erika Lee, and Huping Ling encourage scholars to think beyond the typical geographical boundaries of Asian America. ${ }^{13}$

The story of Filipino American anti-martial law activism in the 1970s and 1980s challenges reductionist ideas of midwestern modesty, immigrant apathy, and the Asian American "model minority." Moreover, this article highlights the significance of Chicago in American radicalism, opening up another space for scholars to explore what it means to be politically transgressive and to be politically transgressive and nonwhite in America's heartland, particularly in the final decades of the Cold War. Most important, the narrative of midwestern anti-martial law organizing geographically and temporally destabilizes Asian American and Filipino American master narratives, forcing scholars to be dynamic, cognizant of complexities and problematic binaries, and mindful of conveniently tidy and contained histories of Asian America.

\section{Contemporary Filipino Immigration and Activism in the Midwest}

As witnessed in cities across California and the Northeast, Filipino immigration to Chicago soared in the late 1960s. The passage of the 1965 Hart-Celler Act facilitated greater immigration to the United States since the law eliminated quota systems based on national origin, allowed for family reunification, and established an immigrant preference system based on occupation. Since Philip- 
pine schools and universities were modeled after US institutions and because English was regularly taught in Philippine classrooms, American companies welcomed Filipino immigrants to their workplaces. Moreover, Filipinos were ideal workers for American employers since they (often unknowingly) accepted lower pay, put in more hours, and, if visiting under a temporary work visa, were vulnerable to deportation, forcing immigrants to submit to employers' demands.

On the one hand, Filipinos were aggressively recruited by American businesses and were lured in with-if not coerced by - the promises of a better life. On the other hand, many women and men willingly immigrated. In the 1960s and 1970s, limited economic opportunities in the Philippines, coupled with high demand for white-collar and medical professionals, enticed educated immigrants to move to America. Filipinos acquired positions as nurses, doctors, accountants, and engineers in hospitals, firms, and universities across metro Chicago, providing a steady stream of workers in fields with shortages. ${ }^{14}$ This trend continued well into the 1990s. By 2000, 95,298 Filipinos lived in greater Chicago, 32,266 of whom resided within city limits. ${ }^{15}$ This was a stunning shift from a city of 3,554 Filipinos in $1960 .{ }^{16}$ During the Marcos era alone (19651986), approximately 300,000 Filipinos moved to the United States. ${ }^{17}$

Besides limited career opportunities and political crises, post-1965 Filipinos were motivated to flee the homeland in part because of US cultural productions distributed throughout the Philippines that glorified the material benefits of American life. ${ }^{18}$ Filipino immigrants regularly read literature and watched American programming that portrayed life in the United States as an egalitarian society where "rags to riches" stories and the "American Dream" were easily possible with hard work. While post-1965 Filipino Americans embraced American living and sought full inclusion as immigrants, many still remained connected to the homeland through media and product consumption. Even in matters of socialization, Filipinos in Chicago, for example, found camaraderie with other Filipinos but remained loyal to their specific hometown identities as a way of retaining localized Philippine customs. As historian Barbara Posadas notes, "Although from a single nation, Filipino immigrants are simultaneously united and divided by provincial and language loyalties and have tended to form associations, in part, on the basis of these loyalties." ${ }^{\prime 19}$ And unlike earlier waves of Filipino immigrants, post-1965 immigrants were generally more mobile, allowing sentiments for Philippine nationalism to be easily transportable across space and time.

Compared to their pre-1965 counterparts whose working-class occupations encouraged labor unionization and leftist political views, post-1965 Filipino immigrants infrequently aligned with liberal or progressive politics since many lived comfortably as white-collar professionals. For this immigrant cohort, those who achieved the post-World War II "American Dream" signified a willingness or ability to assimilate..$^{20}$ Ultimately, domestic expectations (e.g., marriage, child rearing, and suburban home ownership) to live the "American Dream" disciplined immigrants to practice middle-class conformity and 
complicity because it conferred mainstream acceptance. Moreover, post-1965 Filipinos' more moderate or conservative leanings rested on practices acquired in the homeland. Despite a brief democratic period (1946-1972) in the Philippines, Filipinos who lived under martial law were conditioned to not question authority or social convention. They transported those customs, beliefs, and views of governance to the United States.

For some, geography was a major factor in determining how Filipino immigrants politically aligned. A 1982 study of anti-Marcos opposition groups found that Filipinos in West Coast cities such as Los Angeles and San Francisco were among most active communities because of the region's "historical tradition of political activism." The study alluded to the presence of pre-1965 Filipino agricultural and cannery workers with their histories of class-based labor organizing across California and the Pacific Northwest during the 1930s and 1940s. East Coast Filipinos, they noted, were also politically conscious but, "perhaps on account of their rapid social advancement, showed a smaller amount of political activism," suggesting that Filipino immigrants in New York or Philadelphia were more career driven, urbanized, and thus busier or less worried about financial stability or social integration. ${ }^{21}$ Like other earlier studies of Filipino America, midwestern Filipinos were largely invisible in this survey.

Class aside, in the 1970s and 1980s, many Filipino American activists along the coasts believed that Chicago contained politically conservative immigrant communities. Activists equated their right-wing leanings to their Midwest location, while others believed that the high concentration of immigrants from Ilocos-a poor region in the Philippines as well as Marcos's birthplace-fostered less cosmopolitan worldviews. ${ }^{22}$ On the contrary, Filipino Chicago was a major hub of anti-martial law activism. The issue of martial law invigorated liberal Filipinos and those who sympathized with religious or secular social justice and civil rights causes. They, in turn, would radicalize apathetic or conservative immigrants who learned about on-the-ground realities in the Philippines. Activists educated their civically indifferent countrymen and provided convincing and emotional evidence to demonstrate how America's relationship with the homeland directly affected their lives in the United States.

\section{The Anti-Martial Law Movement Begins}

On September 21, 1972, Marcos declared martial law (Proclamation No. 1081), suspending constitutional liberties across the island nation. Under the specter of the global Cold War, Marcos feared a communist takeover amid increasing civil unrest among the agrarian and urban poor. For Filipino immigrant activists, the United States and their homeland remained closely - and problematically - allied. Various American presidential administrations from Lyndon B. Johnson to Ronald Reagan were mum on their intimate ties to Marcos's Philippines. American officials praised Marcos's staunch stand against communism but often turned a blind eye to Marcos's human rights abuses, knowing 
that upsetting him would undermine America's Cold War sphere of influence in Asia. ${ }^{23}$ Although America claimed that the Philippines was an independent state and free of their support, the legacies of and connections to US colonialism remained evident throughout the island nation. The presence of US military bases (Clark air and Subic naval), along with the prevalence of American capitalism, economic enterprise, and popular culture, suggested that the Philippines remained dependent on the United States. In turn, leftist Filipino immigrants claimed America was partly to blame for the political and economic conditions of their homeland; activists believed America's denial of on-the-ground realities helped sustain martial law.

The same day Marcos enacted Proclamation No. 1081, a gathering of Filipino progressives took place in San Francisco. Mostly Philippine- and some US-born Filipino Americans created the National Coalition for the Restoration of Civil Liberties in the Philippines (NCRCLP), the first organized US-based opposition to the Marcos dictatorship. ${ }^{24}$ Headed by former Philippine Communist Party activist Melinda Paras, the NCRCLP "united around the principles of 1) opposition to martial law, 2) restoration of civil liberties, 3) release of political prisoners, and 4) end of US support to Marcos.. ${ }^{25}$ The NCRCLP also sought to deepen the theoretical orientation of immigrants who they felt were too complicit with the status quo. ${ }^{26}$ They encouraged Filipinos to read Lenin, Marx, and Mao and to not buy into myths of "petit bourgeois" consumerism or assimilation as markers of proper American citizenship. ${ }^{27}$ Those views, however, generally did not sit well with Filipinos in the shadow of the Cold War.

Shortly after the NCRCLP's establishment, in July 1973, about eighty native- and foreign-born Filipinos founded Katipunan ng mga Demokratikong Pilipino (KDP) ${ }^{28}$ Its founders wrote, "[In] the struggle for national democracy in the Philippines," the KDP must address the "exploitation and racist oppression of U.S. monopoly-capitalism" in America and in the Philippines. ${ }^{29}$ From their perspective, the West's imperialism, militarism, white supremacy, and capitalism were interconnected forces sustaining inequality around the world, especially in the "Global South" or "Third World." The KDP, along with other US-based Filipino-led liberal and progressive organizations, such as Friends of the Filipino People (FFP), the Movement for a Free Philippines (MFP), and the Ninoy Aquino Movement (NAM), organized a large albeit fragmented movement to end martial law and Marcos's controversial dictatorship. Inspired by the Third World movement in the United States, the KDP positioned themselves as an antiracist, anti-imperialist, and anticapitalist organization. Like their Black, Brown, Red, and Yellow Power counterparts, they embraced a militant persona; espoused communistic and socialistic views; spoke out against US-led wars in Vietnam, Laos, and Cambodia; advocated for antiracist policies; and abided by the mantra "serve the people." ${ }^{30}$ They openly supported radical organizations like the Palestine Liberation Organization and the Viet Cong and sought an end to all US interventions in and ties to the Philippines. KDP activists believed that 
the structural legacy of US imperialism prevented the Philippines from sustainable growth and true independence.

Most NCRCLP chapters were soon replaced by the Anti-Martial Law Coalition and, later, the Coalition Against the Marcos Dictatorship/Philippine Solidarity Network (CAMD/PSN) ${ }^{31}$ Eventually, these groups were then converted to KDP satellites with chapters in Guam, Honolulu, San Diego, Los Angeles, Oakland, Sacramento, San Jose, Seattle, Chicago, New York, Washington, D.C., and Philadelphia. By the late 1970s, the KDP had grown into a significant grassroots organization. However, with only a handful of folks willing to give up their day jobs for the cause, the KDP "refocused its energies" and maintained its strongest networks in California, Hawaii, New York, Washington, and Washington, D.C. ${ }^{32}$

Other anti-martial law organizations formed in the 1970s. Founded in 1973 and based in Philadelphia, FFP professed a centrist approach in the antimartial law movement. ${ }^{33}$ Like KDP, they opposed US aid to the Marcos dictatorship, protested human rights abuses, and supported "the Filipino people in their efforts to secure social and economic justice and full freedom and independence." ${ }^{34}$ Under the direction of Boston-based New Left historian Daniel Boone Schirmer, FFP members generally came from the East Coast and Midwest. ${ }^{35}$ Unlike the KDP, whose hypernationalist and militant reputations deterred some whites from joining, FFP received support from many non-Filipino activists and intellectuals. Schirmer especially helped garner attention about Philippine issues from empathetic white liberals, such as famed Chicago radio host and activist Studs Terkel. ${ }^{36}$ FFP members worked within the parameters of the state, lobbying congressmen, public authorities, and nonprofit organizations to end martial law and the Marcos regime. They wrote letters, held community and church meetings, and devised other "practical" approaches.

Filipino Americans lukewarm to KDP and FFP joined two other organizations: MFP and NAM. Chicago Methodist minister Leo Constantino noted that Filipinos wary of getting involved waited until "celebrity politicians" endorsed particular organizations. When MFP and NAM recruited former Philippine senators Raul Manglapus and Heherson Alvarez to serve as the faces of these organizations, less active or moderate critics of martial law joined. Manglapus was an unapologetic progressive who served in the Philippine Senate. Alvarez was an advocate of agrarian Filipinos and held office in both the Philippine House of Representatives and the Philippine Senate. Manglapus's high profile also caught the eye of more mainstream white liberals. Bruce Cameron of Americans for Democratic Action attempted to join forces with MFP since Manglapus's affiliation legitimized the movement. ${ }^{37}$ As anti-martial law activists Madge Bello and Vincent Reyes noted, the US-based opposition to martial law broadened its appeal when MFP was established. Both MFP and NAM shunned Marcos and America's involvement in Philippine politics, but they were still less radical than the KDP. For example, MFP vocally warned of the "danger of communism" permeating the United States and the Philippines. ${ }^{38}$ MFP leaders did not 
always work with the KDP because of their explicit support of the Philippine Communist Party and the New People's Army (NPA). MFP members believed that the anti-martial law battle was best fought within the powers of the state and with less ideologically extreme allies. Not surprising to some elite martial law activists, MFP and NAM claimed that they found some of their strongest support in Chicago, suggesting that Filipinos in the heartland espoused more centrist views than their coastal counterparts. Nevertheless, progressive factions like the KDP still heavily relied on the Midwest even while liberal groups charged that they were too radical for Filipino Chicago.

Together, these US-based organizations created a transnational activist network and formed the largest Filipino American social movement in contemporary US history. Despite internal fissures, as Jose Fuentecilla noted, "the disparate personalities of its leaders were bound together by one overarching commitment - the overthrow of a Philippine dictator" whose personality and policies symbolized the legacies of colonialism, extreme capitalism, and militarism. ${ }^{39}$

In greater Chicago, two institutions were critical interlocutors between these activist organizations and Filipino Americans: the Pinoy newspaper and the United Methodist Church of Illinois. While explicitly not in the realm of either grassroots or high politics, their participation reveals the multiplicity of Chicago-based actors in the campaign to end martial law. Nevertheless, their acts were political in nature even if their primary duties were, respectively, journalism and religious proselytizing.

\section{Start Spreading the News: Martial Law and Pinoy}

Although the groundwork, rallying, and organizing of the KDP, FFP, MFP, and NAM were crucial in the movement, the widespread dissemination and consumption of anti-martial law news and propaganda encouraged everyday Filipinos to take action. In Robert E. Park's 1922 study of immigrant presses, the Chicago School sociologist noted that ethnic newspapers helped acculturate immigrants into their host countries. ${ }^{40}$ Filipinos were no exception..$^{41}$ Filipino American newspapers detailed current events in both the United States and the Philippines. Reporters selected big stories that they believed were important for the greater Philippine diaspora. These ethnic weeklies were also vital for newly arrived immigrants seeking necessities like employment and housing. They served as a mode for social networking as well listing missed connections, event dates, or meeting times for their hometown provincial associations.

During the anti-martial law movement, however, a number of Filipino American newspapers challenged Park's theories about newspapers as a vehicle toward mainstream assimilation. Ethnic newspapers often encouraged Philippine nationalism rather than full American assimilation. They touted global Filipino pride, scorned Marcos, and criticized US policies in print and on the streets. At the same time, their civic engagement-however nationalistic it was 
to the Philippines - was a testament to their respect for both American participatory democracy and their liberties as US citizens to express multiple cultural affinities. In other words, though anti-martial law activists criticized the state and politics in both America and the Philippines, they were able to articulate those criticisms and prescriptions for the Philippines' future because of their First Amendment rights as Americans. This is not to suggest anti-martial law activists' belief in US exceptionalism. Rather, their actions reveal an ironic dimension in their political mobilization.

Unlike periodicals published by organizations like the KDP, community newspapers had a wider reach and were more accessible to everyday readers. Organizational publications such as the KDP's Ang Katipunan and the CAMD's Taliba promoted mainly anti-imperial, antifascist, and anti-Marcos critiques. Often, particularly for recently settled or less politically inclined immigrants, articles about critical theory, philosophy, or public policy made these periodicals less than democratic. In contrast, community newspapers were typically less politically explicit but were just as important in the distribution of liberal and radical thought. Toronto's Balita, Chicago's Philippine Times, and South San Francisco-based and nationally published Philippine News promoted pure democracy, openly criticizing the fascist state of martial law. ${ }^{42}$ These ethnic newspapers were polemical but approachable and local yet global. Because stacks of these newspapers were available in Filipino grocery stores or community centers, they were also easier to obtain. As Benito Vergara notes, these periodicals featured a "strong, if not dominating, orientation toward current events in the Philippines - a good example of transnationality, in all its ambiguity, at work." 43

In Chicago and the greater Midwest, the Philippine Times was the principal news source of the Philippine diaspora. The Philippine Times dissolved in 1977. Shortly after, the Filipino American weekly Pinoy emerged as the community's primary outlet. Like other immigrant-run periodicals, Pinoy promoted cultural preservation and ethnic pride. At the same time, it refrained from perpetuating ideas that immigrants were indebted toward the United States for their right to achieve the "American Dream." As scholars of post-1975 Vietnamese refugees have pointed out, representations of Asian immigrant gratitude and proAmericanism were prevalent themes in mainstream US media like CBS News. Journalists narrated rosy stories of the United States as arbiters of justice and opportunity, conveniently omitting America's heavy hand in foreign, economic, and military policies that facilitated these exoduses from Asia. ${ }^{44}$

Rather than espousing pro-US views, every edition of Pinoy pushed immigrants to think critically about their position in their new home of America. Although many post-1965 Filipino Americans steadily joined the middle class and lived in better conditions than in the Philippines, Pinoy writers reminded readers that, overall, Filipinos still lacked cultural capital around the world. Accordingly, Pinoy contributors urged readers to not turn a blind eye or forget about issues of inequality in both the Philippines and America. 
Pinoy's founder, Mariano "Anong" Santos, was the force behind the provocative periodical. Santos resettled from Tarlac-Tarlac, Philippines, to Chicago in 1970 to work as an architect. He took up journalism as a hobby but eventually devoted his full-time career to writing as the militarization of martial law intensified. Between 1971 and 1977, Santos wrote for the Philippine Times. Shortly after the paper folded, he founded Pinoy, which operated until February 1979, when Santos decided to pursue a graduate degree at the University of Illinois, Chicago. ${ }^{45}$ Although the paper's run lasted only two years, Pinoy was a major community resource for Filipino immigrants. The newspaper was widely distributed every week to Filipino grocery stores, restaurants, travel agencies, car dealerships, and homes across Chicagoland. With missed connection postings, event calendars, and photos of recent family or provincial club parties, ethnic newspapers like Pinoy were bridges for connecting kababayans ${ }^{46}$ in the region. As Rick Bonus noted on his research of Filipino immigrant settlements in southern California, community newspapers catering to immigrants gathered information not covered by American mainstream media. ${ }^{47}$

Unlike many periodicals, Pinoy was an important mouthpiece for the antimartial law campaign. Activists in Chicago recognized the potential force of ethnic media and utilized the newspaper. Knowing that Santos was sympathetic to the cause, anti-martial law advocates relied on Pinoy to publish specific articles, op-eds, images, cartoons, and even advertisements that would bring more readers into activist circles. They took advantage of this free space for distributing political propaganda, believing that exposure translated to community consciousness.

On its surface, Pinoy was a niche paper catering to an audience more interested in showbiz and lowbrow culture than current events. Front covers frequently displayed pleasant visuals of recent debutante balls, concerts, or homeland celebrities. Beyond the cover's frills, the reader was quickly taken from soft news to hard-hitting pieces. Pinoy posted reports of Marcos-sponsored abductions, tortures, and killings. They listed the harassment of Marcos critics in both the Philippines and the United States. ${ }^{48}$ Every issue highlighted previous and upcoming anti-martial law rallies and protests in Illinois, Michigan, and Wisconsin and across the Midwest. Aside from martial law articles, Pinoy printed testimonies of workplace discrimination especially among Filipino nurses and doctors in Illinois hospitals, daily encounters with racist microaggressions, and challenges that immigrants faced as newcomers to the United States. Finally, and unusual for most Filipino American community newspapers of the time, Pinoy featured lengthy and thoughtful condemnatory editorials critiquing US-Philippine relations in regards to capitalism and imperialism. Overtly polemical, Pinoy's publications read more like anti-martial law movement flyers. News, especially about Marcos, straddled the line between objective and yellow journalism. But Pinoy's sometimes tabloidlike writing was no mistake; Santos and other contributors hoped to elicit strong reader reactions. 
Even Pinoy's seemingly humorous features were bitter reminders of the calamitous politics of the Philippines. Acerbic cartoons mocked Marcos and other coconspirators, including American officials. In one scathing illustration, Pinoy cartoonist D. de Alcala caricatured Ferdinand and Imelda Marcos as surreptitious money mongers. Another cartoon depicted US Vice President Walter Mondale during his May 1978 visit to the Philippines. Dragging a bag of $\$ 41$ million onto a stage above a crowd of poor Filipinos, Mondale scolds Ferdinand Marcos, saying, "You've been a very naughty, naughty boy, but ..." Nearby, Marcos's daughter is excited by the bounty of American cash. Below, a small bloblike creature jokes, "Wow! May pangshopping nanaman si madama (She has money to shop again)." ${ }^{.49}$ Indeed, the US government funneled monies to the Marcos administration throughout the 1970s and 1980s for economic advancement and as compensation for American military bases. Critics often charged that those funds were mismanaged or pocketed by Marcos's cronies. Pinoy's political cartoons, while meant to trigger laughter, were serious texts that reached wide audiences. These images were subtle ways to remind readers of Marcos's wrongdoings, America's tangled relationship with the Philippines, and why diasporic Filipinos needed to remain invested in the homeland. These everyday publications conveyed to immigrants that what happened abroad affected their present and future lives in the United States.

While substantive news was a primary reason that readers picked up Pinoy, Filipinos also turned to the paper's weekly listings of local excursions. Less conspicuous and often underrecognized was the regularity of religious group involvement with the anti-martial law movement. Buried in lists and dates of provincial club meetings, arts and crafts events, and cultural festivals were notices about Chicago-area church activities or town halls focused on anti-martial law activism and social injustice in the Philippines.

Mirroring the activism of black and white Christian leaders during the civil rights movement, white and Filipino Catholic and Methodist clergy took part in the anti-martial law movement. ${ }^{50}$ Their engagement took on various forms, but most religious figures used the power of language to champion their cause. They penned scathing commentaries about Marcos's actions and America's ties to the Philippines. For example, in Pinoy, Filipino American Catholic and Protestant leaders published countless articles about priest abductions and state censorship among outspoken church activists in the Philippines. They articulated reasons why martial law was stripping Filipinos not only of human rights but also of their rights as Christians to live freely and justly. A weekly column by Sister Caridad Guidote, a Catholic nun involved with the Anti-Martial Law Alliance, regularly pled readers to challenge the Marcos regime. She was especially critical of capitalism and suggested that martial law was a product of greed. Guidote criticized the Marcos government for protecting "a heavy concentration of wealth in the hands of a few" and blamed the American government and multinational corporations for taking "advantage of the Philippines' cheap labor and natural resources." ${ }^{51}$ Guidote claimed that media in the United 
States and the Philippines falsely reported stories of an improved quality of life under Marcos. These representations, Guidote alluded, reflected how Marcos exercised his power in covert and overt ways. Indeed, besides the pro-Marcos overtones of state-run Philippine journalism, American media and politicians regurgitated glowing reports about the Philippines. The Marcos administration fed this "official" information to US media. According to Guidote, "The façade of a business boom and prosperity actually hides the ugly reality of this regime of obscene contrasts: between the luxurious mansions of the rich minority in Metro Manila and Makati and the stench shanties of Tondo slums; between the scandalous wealth of the conjugal dictators' clique and the near-destitution of the Pilipino people in general. ${ }^{52}$ From the perspective of Guidote and other Christian leftists, martial law kept the Filipino people in political and economic bondage. While Guidote was among the few Filipino American religious leaders consistently criticizing Marcos, she was not alone. She had a very public and equally vocal counterpart in the Midwest: Leo Constantino and the United Methodist Church of Illinois.

\section{Of Religious Obligation, Not Politics: Martial Law and the United Methodists}

On May 14, 1986, months after Philippine President Ferdinand Marcos was ousted from office, Reverend Leo Constantino of Chicago distributed his sermons about martial law, international human rights, and the fight for democracy and self-determination in the Philippines. A longtime progressive activist in the city, Constantino appealed to Christians who believed that religious obligations were intrinsically tied to issues of social justice. Among Constantino's allies was Resident Bishop Jesse R. DeWitt of Chicago's United Methodist Church. In the forward of Constantino's sermon collection, DeWitt acknowledged the place of religion in political struggles around the world: "To equate the events of history with the intentions of God is to reaffirm the Divine Plan of Creation and to give significant meaning to the coming of Christ and the Promise of a New Age. ${ }^{{ }^{53}} \mathrm{He}$ reminded fellow Methodists that true acts of discipleship included helping the helpless and marginalized.

Throughout the 1980s, Chicago Methodists like Constantino openly criticized martial law, the Marcos administration, and US foreign policy that retained Marcos's authority. The United Methodist Church of Illinois regularly published articles or held rallies, teach-ins, and community forums on human rights, militarism, and imperialism. ${ }^{54}$ The increasing focus on martial law encouraged Methodists to turn their attention to other parts of the global South or Third World as well. Methodist churches across greater Chicago educated parishioners on controversial topics, such as the Iran-Contra scandal, racial apartheid in South Africa, and militarization in Korea. ${ }^{55}$ Methodist ministers also encouraged public conversations on problems "at home," including racism and xenophobia in the Midwest. Localizing civil rights as it related to global 
geopolitics mirrored the secular approaches of Yellow Power activism across the West Coast in the late 1960s and 1970s. But unlike the overtly polemical, radical, and nationalistic agendas of the Red Guard or I Wor Kuen, for example, Methodists positioned their activism as acts of godliness, humanitarianism, and multicultural civility. ${ }^{56}$ For example, in November 1983, Asian Methodists in Chicago held a two-day conference on racism targeted toward students and young adults. Among the panels was a discussion about "The Effects of U.S. Involvement in Asia: Past and Present." Embodying the Methodist Church's emphasis of connecting the local to the global, this panel featured Asian American reverends, including Filipino activist Rey Lopez. Lopez used this opportunity to publicly discuss how the plight of Filipinos at home and abroad was a reflection of failed US foreign policy. ${ }^{57}$ Along with community meetings, active Methodists wrote critical op-eds in church bulletins, ethnic newspapers, and mainstream periodicals across the Midwest to raise awareness of international affairs like martial law.

While Filipino immigrants were overwhelmingly Catholic (approximately 90 percent), some converted to Methodism in the 1970s and 1980s due to the Methodist Church's active recruitment. In 1975, the United Methodist Church said that it was a "missional priority" to gain "ethnic" membership in order to diversify their congregations. ${ }^{58}$ In 1980, the official caucus of the Asian American United Methodists announced their goal of increasing the number of Asian American Methodists by 24,000 in four years. Their plan, called "Ripe for Harvest," included recommendations such as developing "sister church" relations between Asian American congregations and those in Asia. Another goal suggested that the Methodist Church should officially support imprisoned government critics in politically unstable countries like the Philippines. ${ }^{59}$

With the exception of Koreans whose mission-based ministry in Chicago traced back to 1923, Methodists faced difficulties recruiting Asian Americans in Illinois. ${ }^{60}$ In the 1970s and 1980s, Methodist ministers identified Vietnamese, Hmong, and Chinese immigrants as possible converts. Church leaders also hoped to attract Filipinos since they were among the fastest-growing immigrant communities in Chicago. To formally recognize this burgeoning constituency within the church, in 1977 a group of Filipino Methodists founded the United Filipino Church of Chicago. They reorganized in 1983 as a mission church of the United Methodist Church and officially became part of the Northern Illinois Conference. ${ }^{61}$

Methodists suggested that they could make inroads with Filipino immigrants since most fled the homeland during martial law. Immigrants' experiences with or observations of human rights abuses and corruption in the Philippines made them prime candidates for the type of holistic social justice, missionary, and liberation theology projects that Methodists claimed to have an advantage over the Catholic Church. As Methodist Bishop Nacpil noted in his defense of charity work in the Philippines, "We can fight against human rights violations, imperialism, sexism, racism. . . . We can say 'amen' to that. But we 
must ask, 'Is that all?' Is not mission more than man's love for man? Mission is not a humanistic activity. It is an evangelical exercise. Jesus tells Nicodemus, 'You must be born anew." 62 Chicago Methodists appealed to some liberal and anti-martial law Filipino immigrants through discourses of spiritual revivalism and, in turn, widened their constituency. Yet Asian American membership remained low in the church. Nevertheless, Filipino Methodists made waves in the 1980s. They sat in leadership roles and exercised their influence to promote the anti-martial law campaign. They also used church teachings to get Methodists across racial lines involved with the movement.

Filipino Methodist involvement in the anti-martial law movement also encouraged non-Filipino members to internationalize their worldview. In many ways, Filipino American activists influenced their white counterparts to join in the cause because they crafted religious-based activism as an act of global cosmopolitanism. They did this by touting nationalism as an elastic concept. Filipino Methodist activists argued that human suffering was a universal issue and pitched their cause as a value-laden, ethical, and therefore religious problem rooted in economic and political greed. Ultimately, according to Constantino, Filipinos were invested in the anti-martial law movement because they shared a system of beliefs; they emphasized and embodied the dynamism of community and wholeheartedly believed in the struggle for human dignity. ${ }^{63}$

At the height of martial law, Filipino Methodists in Chicago partnered with leftist anti-martial law organizations for collective action. They helped coordinate crucial visits from Philippine-based anti-martial law advocates, including prominent anti-Marcos critic Ninoy Aquino. Because of Constantino's charismatic reputation in Chicago and his deep ties to progressive activists in the Philippines, he played a key role in Aquino's 1981 visit to Chicago. Constantino handled the logistics of his trip, including finding a safe place for him to stay amid rumors of an assassination attempt (Aquino was assassinated in the Philippines on August 21, 1983). ${ }^{64}$ With the assistance of Ed Monteclaro, he staged a successful political tour as Aquino worked to build a strong anti-martial law base in Illinois. During his stay, Aquino found and forged a solid network of anti-imperialists, socialists, and Marcos administration watchdogs in Chicago, promising to back the anti-martial law cause. This partnership helped create an anti-martial law movement in the United States that was truly national rather than a campaign centered primarily in San Francisco and New York City.

Throughout the early and mid-1980s, Constantino urged his fellow Methodist ministers to make the anti-martial law movement a major topic of discussion in their respective churches. He effectively used the bully pulpit to raise awareness. Constantino did not shy away from likening Marcos's policies to acts of fascist dictatorship. He delivered passionate sermons linking issues such as poverty and disenfranchisement to deliberate structures of inequality rooted in - and what would later be understood as - the dual phenomena of globalization and neoliberalism. He frequently spoke on matters of civil liberties and listed reports of human rights abuses in the Philippines. Constantino 
often called out the "First World" for exploiting the "Third World" and used the neocolonial relationship between America and the Philippines as a prime example. At the same time, Constantino was cautious with his words, knowing that Ilocanos would not be fond of his anti-Marcos condemnations. ${ }^{65}$ Nevertheless, he explained to congregations why the anti-martial law campaign was not about politics but was, from his standpoint as a Methodist, a moral and religious obligation.

As Marcos's force continued to weigh heavy over the Philippines in the early 1980s, the Methodist Church sharpened their critiques of US-Philippine relations, believing, like the broader anti-martial law coalition, that the American government was heavily responsible for retaining Marcos in power. The Northern Illinois Conference, in particular, distributed news about human rights issues, religious censorship, and Christian activists condemned and/or captured in the Philippines. ${ }^{66}$ The conference's official newspaper, the United Methodist Reporter/United Methodist Review, ${ }^{67}$ publicized rallies and workshops about martial law encouraging non-Filipinos to join the cause.

These efforts, coupled with Constantino's tours of Filipino Methodist churches and leftist organization meetings, facilitated a public consciousness that extended beyond the realm of Filipino immigrants. By positioning the anti-martial law movement as one of religious obligation rather than arbitrary grievances about the state, capitalism, and foreign relations, Filipino Methodists in Chicago convinced their midwestern neighbors and allies that this issue was above the domain of partisan politics. In their eyes, calling for an end to martial law - and, relatedly, an end to racism, militarism, and violence around the world - was the just, Christian thing to do.

Putting aside the truism of midwestern modesty, Filipino Methodists, leftist groups, and their Chicago allies showed anti-martial law activists across the United States and around the world that they were raising hell in the heartland. Particularly for Filipino immigrants in Chicago, having Methodists' support was another example of how the politics of martial law transcended religious, cultural, and ideological borders. Like the ethnic press, Methodists proved to be an indispensable resource for activists and immigrants. They relied on these networks to create communities of belonging and, in light of the anti-martial law campaign, communities of civic engagement encouraging Filipino immigrants to exercise their democratic rights even if their views countered prevailing sentiments of both their homeland and their new home of America.

\section{Martial Law Ends}

In late February 1986, Marcos was ousted from the presidency during the People Power Revolution. When a snap election earlier in the month declared Marcos the victor against Corazon Aquino-widow of slain anti-Marcos activist Ninoy Aquino - poll watchers, Catholic church leaders, and millions of Filipino voters alleged that Marcos tampered with election results. Two weeks 
later, from February 22 to February 25, protestors marched against Marcos's "victory" on Epifiano de los Santos Avenue (EDSA), pressuring Marcos to step down. With the aid of President Ronald Reagan and the US government, Marcos vacated Malacañang Palace and was flown to Hawaii, where the Marcos family lived in exile. Ferdinand died in Honolulu in September 1989, and three years later, Imelda returned to the Philippines. The People Power Revolution was one of the most impressive nonviolent coups d'etat in the twentieth century, inspiring subsequent social movements in South Asia, Africa, and Eastern Europe.$^{68}$ Like their Filipino counterparts in the United States, EDSA protestors in the Philippines illustrated the power of collective action from everyday people.

When Reagan suggested that the US government played a key role in the People Power Revolution, critics in Chicago quickly shot back. Leo Constantino stressed the agency of the Filipino people and bemoaned suggestions that the American government saved the Philippines from further instability. In an editorial, Constantino noted that it was "the Filipino people [who] brought the Marcos house down." ${ }^{\circ 9}$ Many scholars concurred. Political scientist Stephen Zunes argued it was the "well-organized armed resistance movement ... [from] the Communist Party and New Peoples Army (NPA)" that facilitated the eventual uprising. ${ }^{70}$ Moreover, as sociologist and Quaker activist George Lakey observed, the Philippine Catholic Church and leftist organizations educated the pastoral peasantry and urban poor to catalyze revolt. They developed "an analysis of the ills in Philippine society" and crafted a "vision of what a liberated society would look like and strategies of how to get there." " Similarly, in the United States, Filipinos' on-the-ground activism raised consciousness among immigrants who subscribed to conservatizing notions of cultural assimilation as signifiers of social respectability. Filipino anti-martial law advocates in Chicago urged immigrants to be mindful of the various structures of inequality that surrounded them. Their marginalized status in the Philippines and their liminal position in the United States encouraged activists to participate in the struggle to end martial law and, relatedly, matters of global inequality tangled in the forces of capitalism, imperialism, bigotry, and American exceptionalism.

American-based activists did not always directly collaborate with Philippine-based activist networks simply because of distance. Moreover, a lack of resources and monies made it difficult to sustain some semblance of regular communication. But collectively, these disparate networks successfully helped restore democracy in the Philippines, brought increased attention to international oppression and discrimination, and fostered an imagination for alternative forms of citizenship detached from state authority, or, in other words, a way of thinking about citizenship as one that could be experienced even as formal regimes of power denied full recognition or rights to the wider Philippine diaspora.

As this article demonstrated, excavating and narrating the experiences of Asian Americans in the Midwest exemplifies the diversity as well as the com- 
monalities of Asian American lives across the United States. Through the story of Filipino American anti-martial law activism in Chicago, we can better understand the political, social, and cultural importance of the geographic "middle." Filipinos in Chicago and the greater Midwest were minimally credited for their mobilization efforts, but as this article illustrated, their combined acts of resistance significantly contributed to an international political movement often understood as rooted along the coasts. The groundwork of Filipino Chicago's leftist organizations, aided by the support of religious groups and ethnic media, helped keep the global anti-martial law movement alive and relevant. Immigrants involved with the movement, in particular, exercised their agency and showed how one group of Asian Americans exemplified traits antithetical to the "model minority." cence and insularity, heartland restraint, and Chicago's racial separatism, this extensive network of creative and determined globally-minded Filipino Americans demonstrated the ways in which Chicago was and has long been a diverse metropolis of renegades, rebels, and immigrant ingenuity.

\section{Notes}

1. A number of articles on the anti-martial law movement were published in the late $1980 \mathrm{~s}$ and 1990s. Many were written by anti-martial law activists. A few key works include Madge Bello and Vincent Reyes, "Filipino Americans and the Marcos Overthrow: The Transformation of Political Consciousness," Amerasia 13, no. 1 (1986-1987): 73-83; Barbara Gaerlan, "The Movement in the United States to Oppose Martial Law in the Philippines, 1972-1991: An Overview," Pilipinas 33 (Fall 1999): 75-98; Helen C. Toribio, "We Are Revolution: A Reflective History of the Union of Democratic Filipinos (KDP)," Amerasia 24, no. 2 (1998): 155-77; and Daniel Boone Schirmer and Stephen Rosskamm Shalom, eds., The Philippines Reader: A History of Colonialism, Neocolonialism, Dictatorship, and Resistance (Boston: South End Press, 1987).

2. For a recent study on the anti-martial law movement, see Jose V. Fuentecilla, Fighting from a Distance: How Filipino Exiles Toppled a Dictator (Urbana: University of Illinois Press, 2013).

3. For literature on Korean adoption and their ties to the Midwest, see Kathleen Jasook Bergquist, M. Elizabeth Vonk, Dong Soo Kim, and Marvin D. Feit, eds., International Korean Adoption: A Fifty-Year History of Policy and Practice (New York: Routledge, 2007); Catherine Ceniza Choy, Global Families: A History of Asian International Adoption in America (New York: New York University Press, 2013); and Eleana Kim, Adopted Territory: Transnational Korean Adoptees and the Politics of Belonging (Durham, NC: Duke University Press, 2010).

4. For literature about Filipino American settlement and on "mapping" Filipino America, see Rick Bonus, Locating Filipino Americans: Ethnicity and the Cultural Politics of Space (Philadelphia: Temple University Press, 2000); Cindy I-Fen Cheng, "Identities and Places: On Writing the History of Filipinotown, Los Angeles," Journal of Asian American Studies 12, no. 1 (February 2009): 1-33; Linda España-Maram, Creating Masculinity in Los Angeles'Little Manila: WorkingClass Filipinos and Popular Culture, 1920s-1950s (New York: Columbia University Press, 2006); Yen Le Espiritu, Filipino American Lives (Philadelphia: Temple University Press, 1995); and Yen Le Espiritu, Home Bound: Filipino American Lives across Cultures, Communities, and Countries (Berkeley: University of California Press, 2003).

5. Barbara Posadas, "Filipinos," Encyclopedia of Chicago online (Chicago: The Newberry Library), http://www.encyclopedia.chicagohistory.org/pages/451.html (accessed November 14, 2015); Barbara Posadas, "Filipino Americans in Chicago," Northern Illinois University, http:// www.niu.edu/cseas/outreach/pdfs/filamschicago.pdf (accessed January 13, 2015).

6. Barbara M. Posadas and Roland L. Guyotte, "Unintentional Immigrants: Chicago’s Filipino Foreign Students Become Settlers, 1900s-1941," Journal of American Ethnic History 9, no. 2 (Spring 1990): 26-48.

7. Lucy Kinsella, "Pullman Porters: From Servitude to Civil Rights," WTTW-PBS Chicago, http://www.wttw.com/main.taf?p=1,7,1,1,41 (accessed November 14, 2015).

8. Estrella Ravelo Alamar and Willi Red Buhay, Filipinos in Chicago (Chicago: Arcadia Publishing, 2001); Roland L. Guyotte and Barbara M. Posadas, "Interracial Marriages and Transna- 
tional Families: Chicago's Filipinos in the Aftermath of World War II," Journal of American Ethnic History 25, no. 2-3 (Winter/Spring 2006): 134-55.

9. Posadas, "Filipino Americans in Chicago."

10. Sucheng Chan, Asian Americans: An Interpretive History (New York: Twayne, 1993), 53, 60-61; Rhacel Salazar Parreñas, “'White Trash' Meets the 'Brown Monkeys': The Politics of Interracial and Gender Alliances between White Working Class Women and Filipino Migrant Laborers in the Taxi-Dance Halls of the 20s and 30s," Amerasia 24, no. 2 (Summer 1998): 115-34; Antonio T. Tiongson Jr., Edgardo V. Gutierrez, and Ricardo V. Gutierrez, eds., Positively No Filipinos Allowed: Building Communities and Discourse (Philadelphia: Temple University Press, 2006).

11. Catherine Ceniza Choy, Empire of Care: Nursing and Migration in Filipino American History (Durham, NC: Duke University Press, 2003), 154-65; Guyotte and Posadas, "Interracial Marriages and Transnational Families"; Yvonne M. Lau, "Re-Visioning Filipino American Communities: Evolving Identities, Issues, and Organizations," in The New Chicago: A Social and Cultural Analysis, ed. John P. Koval et al. (Philadelphia: Temple University Press, 2006), 141-53; Barbara Posadas, "Transnationalism and Higher Education: Four Filipino Chicago Case Studies," Journal of American Ethnic History 32, no. 2 (Winter 2013): 7-37; "Perla Rabor Rigor Compares Life as a Nurse in the Philippines and America, 1987," in Major Problems in Asian American History, ed. Lon Kurashige et al. (Boston: Houghton Mifflin, 2003), 362-64.

12. Yen Le Espiritu, Asian American Panethnicity: Bridging Institutions and Identities (Philadelphia: Temple University Press, 1992); Stephen H. Sumida, "East of California: Points of Origin in Asian American Studies," Journal of Asian American Studies 1. no. 1 (1998): 83-100; Helen Zia, Asian American Dreams: The Emergence of an American People (New York: Farrar, Straus and Giroux, 2000), 47-48.

13. Research in Asian American studies specific to the Midwest include Pawan Dhingra, "Introduction to Journal of Asian American Studies, Special Issue on the Midwest," Journal of Asian American Studies 12, no. 3 (October 2009): 239-46; Kale Bantigue Fajardo, "Queering and Transing the Great Lakes: Filipino/a Tomboy Masculinities and Manhoods across Waters," GLQ: A Journal of Lesbian and Gay Studies 20, no. 1-2 (2014): 115-40; Erika Lee, "Asian American Studies in the Midwest," Journal of Asian American Studies 12, no. 3 (October 2009): 247-73; and Huping Ling, Chinese Chicago: Race, Transnational Migration, and Community since 1870 (Stanford, CA: Stanford University Press, 2012).

14. Choy, Empire of Care, 2; Lau, "Re-Visioning Filipino American Communities," 144-46; Posadas, "Filipino Americans in Chicago"; "Perla Rabor Rigor Compares Life as a Nurse in the Philippines and America, 1987."

15. Posadas, "Filipinos."

16. Ibid.

17. Espiritu, Filipino American Lives, 20.

18. Bonus, Locating Filipino Americans; Jose B. Capino, Dream Factories of a Former Colony: American Fantasies, Philippine Cinema (Minneapolis: University of Minnesota Press, 2010); Espiritu, Home Bound, 3-6, 23-24, 44; Kyeyoung Park, The Korean American Dream: Immigrants and Small Business in New York City (Ithaca: Cornell University Press, 1997), 4, 86; Linda Trinh Vo and Rick Bonus, "Introduction: On Intersections and Divergences," in Contemporary Asian American Communities: Intersections and Divergences, ed. Linda Trinh Vo et al. (Philadelphia: Temple University Press, 2002), 4-5.

19. Posadas, "Filipinos."

20. Espiritu, Home Bound, 3-6, 23-24, 44; Park, The Korean American Dream, 4, 86; Eric J. Pido, "The Performance of Property: Suburban Homeownership as a Claim to Citizenship for Filipinos in Daly City," Journal of Asian American Studies 15.1 (February 2012): 69-104; Vo and Bonus, "Introduction," 4-5.

21. Fuentecilla, Fighting from a Distance, 24-25; Joseph Patrick McCallus, "The Rhetoric of Ethnic Journalism: The Filipino American Press and Its Washington, D.C. Audience" (Ph.D. diss., Catholic University of America, 1987). McCallus's research is noteworthy. The study is focused on Washington, DC, as well as California. McCallus is right in noting California's long history of attracting pre-1965 Filipino immigrants who worked in agriculture and the service sector. However, his analysis of the immediate post-1965 immigrant profile essentializes groups based on stereotypes of West and East Coast proclivities. Both coasts received highly educated, skilled workers who quickly joined the middle class. This was not specific to the East Coast. Job shortages in engineering, medicine, nursing, and other professional fields encouraged employers to aggressively recruit immigrants to fill positions across the United States. Particularly in the medical field, employers hired immigrants on temporary work visas with their citizenship status contingent on job performance and need. The Midwest was also a main receiver of immigrants who held whitecollar jobs. For further information on the histories of Filipino migration to the United States and its relationship to labor, see Rick Baldoz, The Third Asiatic Invasion: Migration and Empire in Filipino America, 1898-1945 (New York: New York University Press, 2011); Bonus, Locating Filipino Americans; Chan, Asian Americans; Choy, Empire of Care; Espiritu, Home Bound; and 
Dorothy Fujita-Rony, American Workers: Colonial Power: Philippine Seattle and the Transpacific West, 1919-1941 (Berkeley: University of California Press, 2002).

22. Renato Ciria-Cruz, oral history interview by author, San Francisco, CA, December 21, 2009; Leo Constantino, oral history interview by author, Chicago, IL, November 23, 2009; Rey Lopez, oral history interview by author, Chicago, IL, November 12, 2009; Ang Aktibista 2, no. 6 (February 6, 1976): 15-16.

23. Stanley Karnow, "Reagan and the Philippines: Setting Marcos Adrift," New York Times, March 19, 1989. Numerous declassified memos and reports from the US Department of State discuss the need to maintain good relations with the Philippines and President Ferdinand Marcos. All documents were obtained from the National Security Archive at Gelman Library, George Washington University, Washington, DC: "Department of State Briefing Paper: US-Philippine Politico-Military Relationship," US Department of State, June 8, 1983, Philippines folder 3848; "Department of State Briefing Memorandum: Your Meeting with Philippine President Marcos, 11:45 a.m., September 16," US Department of State, September 11, 1982, Philippines folder 4418; "Department of State Telegram: US-Philippine Relations: A Current Reading and a Projection Forward," December 1968, Philippines folder 5672; "Department of State: Wolfowitz Visit to Philippines," April 1983, Philippines folder 6028 .

24. Bello and Reyes, "Filipino Americans and the Marcos Overthrow"; Estella Habal, San Francisco's International Hotel: Mobilizing the Filipino American Community in the Anti-Eviction Movement (Philadelphia: Temple University Press, 2007), 70.

25. Toribio, "We Are Revolution," 177; Rodel Rodis, oral history interview by author, San Francisco, CA, December 17, 2009.

26. Rodel Rodis, oral history interview by author, San Francisco, CA, December 17, 2009; Ang Aktibista 1, no. 3 (February 18, 1974): 10; Ang Aktibista 2, no. 6 (February 6, 1976): 16. 1976): 16

27. Ang Aktibista 1, no. 3 (February 18, 1974): 8-10; Ang Aktibista 2, no. 6 (February 6,

28. In Pilipino (Tagalog), Katipunan ng mga Demokratikong Pilipino means "Union of Democratic Filipinos."

29. Katipunan ng mga Demokratikong Pilipino, "Katipunan ng mga Demokratikong Pilipino First National Congress, July 1973," Santa Cruz, CA, July 1973, from the private collection of Abe Ignacio.

30. For information on Third World activism in the 1960s and 1970s, see Habal, San Francisco's International Hotel, and Laura Pulido, Black, Brown, Yellow \& Left: Radical Activism in Los Angeles (Berkeley: University of California Press, 2006).

31. Bello and Reyes, "Filipino Americans and the Marcos Overthrow," 77.

32. Helen C. Toribio, "We Are Revolution."

33. Friends of the Filipino People website, http://fofp.org.index.html (accessed April 14, 2010); "Human Rights and Martial Law in the Philippines: A Report of the FFP/AMLC Investigating Mission 1977 Manila World Peace Through Law Conference” (Oakland, CA: National Resource Center on Political Prisoners in the Philippines, 1977), 35. 2010).

34. Friends of the Filipino People website, http://fofp.org.index.html (accessed April 14,

35. Jim Zwick, "Notice: Death of Daniel B. Schirmer," H-Net, May 9, 2006, http://h-net. msu.edu/cgi-bin/logbrowse.pl?trx=vx\&list=H-USA\&month=0605\&week=b\&msg=amKHfdcvs $/ 4$ $\mathrm{x} 0 \mathrm{rT1qEAd8g \& user}=\& \mathrm{pw}=($ accessed November 14,2015$)$.

36. Mariano Santos, oral history interview by author, Skokie, IL, November 11, 2009.

37. "Pinoy Insider," Pinoy, March 6, 1978, 18.

38. Bello and Reyes, "Filipino Americans and the Marcos Overthrow," 77, 80.

39. Fuentecilla, Fighting from a Distance, x. Issues of progressive Filipino newsletters such as Ang Aktibista document ideological differences (e.g., liberals vs. progressives or radicals) within the broader anti-martial law movement, particularly between the KDP, MFP, and FFP.

40. Robert Ezra Park, The Immigrant Press and Its Controls (New York: Harper \& Bros., 1922), 86 .

41. Bonus, Locating Filipino Americans, 145-48.

42. Benito Vergara, Pinoy Capital: The Filipino Nation in Daly City (Philadelphia: Temple University Press, 2009), 84.

43. Ibid., 82.

44. Yen Le Espiritu, Body Counts: The Vietnam War and Militarized Refugees (Berkeley: University of California Press, 2014), 92. See also CBS News 60 Minutes video with Ed Bradley on Vietnamese refugees and the "boat people" in Malaysia, produced by Andrew Lack, June 24, 1979; Mimi Thi Nguyen, The Gift of Freedom: War, Debt, and Other Refugee Passages (Durham, NC: Duke University Press, 2012); and Brenda M. Boyle, "At Home with the Unhomely: Vietnamese and Iraqi Narratives of Invasion, Occupation, and 'Resettlement," in Representations of War, Migration and Refugeehood: Interdisciplinary Perspectives, ed. Daniel H. Rellstab et al. (New York: Routledge, 2014), 167.

45. Mariano Santos, oral history interview by author, November 11, 2009, Skokie, IL. 
46. Kababayan is a Pilipino (Tagalog) word for "countrymen."

47. Bonus, Locating Filipino Americans, 148.

48. Pinoy, March 6, 1978, 17.

49. "Mondale's Visit and Carter's Crusade," Pinoy, May 16-29, 1978, 3.

50. Several works on the role of religion in the civil rights movement include Frederick C. Harris, Something Within: Religion in African-American Political Activism (New York: Oxford University Press, 1999); Davis W. Houck and David E. Dixon, eds., Rhetoric, Religion, and the Civil Rights Movement: 1954-1965 (Waco, TX: Baylor University Press, 2006); Clarence Taylor, Black Religious Intellectuals: The Fight for Equality from Jim Crow to the Twenty-First Century (New York: Routledge, 2002); Clarence Taylor, "African American Religious Leadership and the Civil Rights Movement," History Now: American History Online, Gilder Lehrman Institute of American History, http://www.gilderlehrman.org/history-by-era/civil-rights-movement/essays/ african-american-religious-leadership-and-civil-rights-m (accessed January 13, 2015); and Johnny E. Williams, African American Religion and the Civil Rights Movement in Arkansas (Jackson: University Press of Mississippi, 2003).

51. Pinoy, September 26, 1977, 5.

52. Pinoy, December 5-18, 1978, 11.

53. Jesse R. DeWitt, "Introduction from Jesse R. DeWitt, Resident Bishop, The United Methodist Church, Chicago Area," introduction to God Bless the Philippines: Sermons, Prayers, and Other Statements on the Philippine Struggle, 1973-1986, by Leo Constantino (unpublished).

54. Ibid.; Leo Constantino, oral history interview by author, November 23, 2009, Chicago, IL; Carolyn Oehler, "Banned Priest Outlines Rights Violations in Philippines," United Methodist Reporter, October 9, 1981, 1; Unknown, "Meet Our People in Mission around the World: David \& Patricia Williams," United Methodist Review Supplement, June 1986, 4-S. After Marcos's deposal, the United Methodist Church and Northern Illinois Conference continued to report about human rights and militarization issues in the Philippines: "Media Linking of Church to Rebels Decried; Philippines Advocacy Not Influenced by Communist Fronts, Churches," United Methodist Review, November 14, 1986; "Mission Journal Advises Caution on Philippines," United Methodist Review, April 18, 1986, 9; "The Philippines: Cause to Celebrate Is Tempered by Military Abuses and Immense Economic Crisis," United Methodist Review, April 18, 1986.

55. Charles Bloomstein, "Pros \& Cons of Disinvestment," United Methodist Review, January 10, 1986, 12; Linda Jones, "Korea Education Series Scheduled at Mayfair UMC," United Methodist Review, April 4, 1986, 12; Norma Kehrberg, "It Was Awesome Year in Human Suffering," United Methodist Review, June 13, 1986, 1; Helen Post, "Resistance Rather Than Resignation,", United Methodist Review, May 31, 1985, 12; Unknown, "Korean Woman Tells of Suffering," United Methodist Review, May 20, 1983, 3.

56. Jeffrey O. G. Ogbar, "Yellow Power: The Formation of Asian-American Nationalism in the Age of Black Power, 1966-1975," Souls 3, no. 3 (Summer 2001): 29-38.

57. "Coming Events: Racism Conference for Asian-Americans," United Methodist Review, November $11,1983,1$.

58. Roy Howard Beck, "Ethnic Numbers Barely Grow despite 'Priority,"” United Methodist Review, February 7, 1986, 3.

59. Joyce Hopkins, “Asian Americans Seek Membership Rise," United Methodist Review, November 28, 1980, 3.

60. Victor T. Fujiu, "The Far East Has Now Become the Near East," United Methodist Review, June 1, 1984, 1.

61. Raymond M. Veh, "Ethnic Congregation Utilizes Historic Church," United Methodist Review, September 20, 1985, 11.

62. Roy Howard Beck, "Global Ministries'New Board Works at Broadening," United Methodist Review, November 2, 1984, 4.

63. Leo Constantino, oral history interview by author, November 23, 2009, Chicago, IL.

64. Ibid.

65. Filipino community leaders in Chicago claimed that the city had a historically larger Ilocano population compared to other major metropolitan areas. Marcos was Ilocano and maintained support from many Ilocano Filipino Americans despite controversies surrounding martial law. For further information on Filipino Chicago's sentiments toward the anti-martial law movement, see Renato Ciria-Cruz, oral history interview by author, San Francisco, CA, December 21, 2009; Leo Constantino, oral history interview by author, Chicago, IL, November 23, 2009; Rey Lopez, oral history interview by author, Chicago, IL, November 12, 2009; and Ang Aktibista 2, no. 6 (February 6, 1976): 15-16.

66. Hopkins, “Asian Americans Seek Membership Rise," 3; Oehler, "Banned Priest Outlines Rights Violations in Philippines," 1; Unknown, "The Church in the World Today: Foreign Bishop Finds Error in Resolutions," United Methodist Reporter, ca. 1980, 2; Unknown, "World Council Protests Arrest of Filipino Official," United Methodist Review, November 28, 1980, 4.

67. While not explained in the historical record and archive of the Northern Illinois Conference, by the mid-1980s, the United Methodist Reporter became the United Methodist Review. 


\section{James Zarsadiaz}

68. Stephen Zunes, "People Power in the Philippines," in Nonviolent Social Movements: A Geographical Perspective, ed. Stephen Zunes et al. (Malden, MA: Blackwell, 1999), 129.

69. "Filipinos Are Aghast at Reagan's Comparison with Nicaragua Contras," United Methodist Review, April 4, 1986, 12.

70. Zunes, "People Power in the Philippines," 130.

71. Ibid., 131.

72. There is robust literature on the "model minority" myth. Some notable works include Erika Lee, The Making of Asian America: A History (New York: Simon \& Schuster, 2015); Janelle Wong, S. Karthick Ramakrishnan, Taeku Lee, and Jane Junn, eds., Asian American Political Participation: Emerging Constituents and Their Political Identities (New York: Russell Sage Foundation, 2011); Ellen Wu, The Color of Success: Asian Americans and the Origins of the Model Minority (Princeton, NJ: Princeton University Press, 2014); and Zia, Asian American Dreams. 